\title{
PENERAPAN ASAS PACTA TERTIIS NEC NOCENT NEC PROSUNT BERKAITAN DENGAN STATUS HUKUM DAERAH DASAR LAUT SAMUDERA DALAM (SEA BED)
}

\author{
Aryuni Yuliantiningsih \\ Fakultas Hukum Universitas Jenderal Soedirman Purwokerto, Jawa Tengah
}

\begin{abstract}
International ocean seabed area out of national jurisdiction recognized as a common heritage of mankind. Its regulations under International authority based on UNCLOS 1982. UNCLOS 1982 didn't universal acceptance because there are several states unwilling consent to be bound by a treaty. In the law of treaty there is pacta tertiis nec nocent nec prosunt principle, means a treaty does not either obligations or rights for a third State without its consent. Nevertheless, rules in a treaty becoming binding upon on third states through international custom and there is a principle has character erga omnes
\end{abstract}

Key Words: pacta tertiis nec nocent nec prosunt principle, legal status, ocean seabed, erga omnes

\begin{abstract}
Abstrak
Daerah dasar laut Internasional dari yurisdiksi nasional diakui sebagai warisan umum umat manusia. Peraturan tersebut berada di bawah otoritas Internasional berdasarkan UNCLOS 1982. UNCLOS 1982 tidak berlaku universal karena ada beberapa negara tidak bersedia untuk terikat dengan perjanjian tersebut. Dalam hukum perjanjian ada prinsip pacta tertiis prosunt nocent, yang artinya perjanjian baik kewajiban atau hak mengikat bagi suatu Negara ketiga meskipun tanpa persetujuan. Namun demikian, aturan dalam perjanjian menjadi mengikat pada negara-negara ketiga melalui adat internasional dan ada prinsip memiliki karakter erga omnes
\end{abstract}

Kata kunci: Asas pacta tertiis nec nocent nec prosunt, status hukum, dasar laut samudra dalam, erga omnes

\section{Pendahuluan}

Daerah dasar laut samudra dalam di luar jurisdiksi nasional (Seabed) merupakan masalah yang sangat menarik, terutama karena pengaturan hukum untuk daerah tersebut hingga kini belum ada. Masalah ini menjadi lebih menarik terutama ketika lahirnya suatu deklarasi yang menyatakan bahwa daerah dasar laut samudra dalam di luar jurisdiksi nasional serta kekayaan alam yang terkandung di dalamnya adalah warisan bersama umat manusia (Common heritage of the mankind/ CHM). ${ }^{1}$

R.R. Churchill and Lowe, 1983, The Law of TheSea, UK: Manchester University Press, hlm. 159.
Sejak jaman dulu, perairan di luar laut teri-torial merupakan wilayah bebas berdasarkan pada asas kebebasan di laut (freedom of the high seas). Setiap negara bebas untuk melakukan pelayaran serta menangkap ikan di perairan tersebut. Masalahnya kemudian timbul ketika hasil penelitian menunjukkan bahwa daerah dasar laut serta tanah di bawahnya yang terletak di laut lepas tersebut mengandung kekayaan mineral yang tak ternilai harganya.

Rezim hukum Seabed adalah salah satu rezim baru yang diterima dalam United Nation Convention on The law of The Sea (UNCLOS) atau Konvensi Hukum Laut (KHL) 1982 dalam Bab XI. Rezim ini dimaksudkan untuk menter- 
jemahkan konsep common heritage of mankind (selanjutnya disingkat $\mathrm{CHM}$ ) ke dalam bentuk institusional. Hal ini terlihat dari adanya pembentukan suatu International Seabed Authority yang diberi fungsi untuk mengorganisasi dan mengontrol segala kegiatan di bagian laut ini. Institusi ini sangat unik mengingat inilah organisasi internasional yang pertama kali mempunyai sumber daya dan jurisdiksi di suatu wilayah.

Konsep CHM itu sendiri telah diterima secara umum melalui Resolusi MU PBB 2794, 1970 tentang Declaration of Principles Governing the Seabed and the Ocean Floor, and the Subsoil Thereof, beyond the limits of National Jurisdiction.

Menerjemahkan prinsip ini dalam realita masih merupakan masalah yang kontroversial yang membagi negara-negara ke dalam dua kubu yang saling bertentangan. Negara-negara maju di satu pihak berpendapat bahwa prinsip CHM sama sekali tidak menutup kemungkinan adanya kebebasan untuk mengeksploitasi dan mengeksplorasi Seabed secara unilateral. ${ }^{2}$

Negara-negara berkembang berpendapat bahwa pada prinsipnya prinsip $\mathrm{CHM}$ adalah ketentuan hukum internasional yang melarang adanya penambangan secara unilateral. Bahkan prinsip CHM tidak hanya melarang pemilikan Seabed oleh negara-negara melainkan juga membebankan kewajiban kepada semua negara untuk secara aktif mengelola wilayah laut ini.

Perbedaan-perbedaan pendirian yang sangat menyolok antara negara-negara yang sedang berkembang dari negara-negara maju mengenai pengelolaan daerah ini merupakan masalah yang sangat menghambat jalannya konferensi. Di satu pihak negara-negara yang sedang berkembang menginginkan agar International Seabed Authority dapat melakukan pengawasan terhadap setiap tahap kegiatan pengusahaan kekayaan alam tersebut mulai dari tahap eksplorasi, produksi, pemurnian, pengangkutan, pemasaran sampai pada penentuan harga. Di lain pihak, negara-negara maju me-

Hasyim Djalal, 1979, Perjuangan Indonesia di Bidang Hukum Laut, Bandung: Binacipta, hlm.113 nginginkan suatu sistem dimana perusahaanperusahaan swasta ini akan diberikan peranan yang lebih aktif dalam setiap tahap kegiatan penggalian, melalui kontrak-kontrak dengan International Seabed Authority. Interpretasi dari negara-negara berkembang ini akhirnya diterima dalam KHL 1982 Bab XI dan bagian inilah yang mengakibatkan negara-negara maju enggan untuk menandatangani Konvensi ini.

Tidak ada yang menyangkal bahwa Konvensi Hukum Laut 1982 sebagai suatu perjanjian internasional yang memiliki karateristik formal dan istimewa. Banyak kalangan menganggap bahwa Konvensi ini menciptakan suatu rezim atas wilayah yang diakui sebagai milik bersama umat manusia. Keunikan KHL 1982 ternyata mensyaratkan semua negara untuk menjadi pihak pada Konvensi ini. Sebelum proses perumusan konvensi ini dilakukan, telah dibayangkan bahwa semua negara akan menjadi pihak dan tidak ada suatu pemikiran bahwa akan ada beberapa negara yang akan berada di luar konvensi, namun di luar dugaan, Amerika Serikat berdasarkan kebijaksanaan luar negeri Reagan yang populer dengan sebutan negotiation from strength ${ }^{3}$ menolak untuk menjadi pihak pada Konvensi. Jejak Amerika Serikat ini diikuti oleh beberapa negara maju lainnya dan menimbulkan apa yang disebut dengan non universal acceptance of the Convention.

Tidak diterimanya konvensi secara universal, pada akhirnya melahirkan suatu pertanyaan besar dan menarik tentang status hukum dari rezim Seabed ini. Tidak disangkal bahwa sasaran utama yang hendak dicapai melalui rezim ini tidak mungkin terwujud jika terdapat pihak ketiga pada konvensi ini yang secara tegas menolak berlakunya Bab XI. Dilihat dari segi hukum perjanjian internasional, tidak diterimanya secara umum rezim ini tidak hanya mengakibatkan rezim ini tidak efektif tetapi juga menimbulkan konflik norma dan bahkan

Negotiation from strength adalah kebijaksanaan luar negeri pada masa pemerintahan Reagan yang berhaluan keras yang ditujukan pada Uni Soviet semasa Perang Dingin. Kebijakan berhaluan keras ini terpenetrasi ke bidang lainnya seperti UNCLOS III. 
mengakibatkan status hukumnya semakin tidak menentu. ${ }^{4}$

Salah satu ciri yang penting adanya rezim ini adalah terjadinya suatu konversi rezim atas wilayah yang dulunya merupakan rezim laut bebas berubah menjadi rezim Seabed/CHM. Perubahan rezim ini tentunya menuntut suatu pemberlakuan secara umum untuk semua negara dalam arti tidak mungkin rezim ini diterapkan terhadap sebagian negara, sementara negara-negara yang lain menerapkan rezim yang lama. Telah dibayangkan oleh negara peserta konferensi bahwa tidak mungkin terdapat dua rezim yang berbeda terhadap satu wilayah yang sama. Itulah sebabnya redaksional Konvensi ini dibuat sedemikian rupa sehingga mengindikasikan bahwa rezim ini berlaku secara universal terhadap semua negara. Istilahistilah seperti all states, every state dan no state disamping state parties banyak digunakan dalam Bab ini membuktikan maksud tersebut.

Persoalan hukum lainnya akan muncul adalah Apakah rezim seabed ini tidak melanggar prinsip hukum perjanjian pacta tertiis nec nocent nec prosunt, yaitu bahwa suatu perjanjian tidak akan memberikan kewajiban dan hak bagi pihak ketiga tanpa persetujuannya?

\section{Pembahasan}

\section{Hukum Perjanjian Internasional}

Pengertian umum, perjanjian internasional adalah kata sepakat antara dua atau lebih subyek hukum internasional mengenai suatu obyek atau masalah tertentu dengan maksud untuk membentuk hubungan hukum atau melahirkan hak dan kewajiban yang diatur oleh hukum internasional. ${ }^{5}$

Menurut Pasal 2 Konvensi Wina 1969, Perjanjian internasional atau treaty adalah suatu persetujuan yang dibuat antara negara dalam bentuk tertulis dan diatur oleh hukum internasional, apakah dalam instrumen tunggal atau dua atau lebih instrumen yang berkaitan dan apapun nama yang diberikan.

Jesper Grolin, 1984, The Future of The Law of The Sea, ODIL, hlm.20

5 I Wayan Parthiana, 2002, Hukum Perjanjian Internasional Bag. I, Bandung : Mandar Maju, hlm.12
Ditinjau dari kaidah hukum yang berlaku, perjanjian internasional dibedakan menjadi dua yaitu treaty contract dan law making treaty. Treaty contract adalah perjanjian yang hanya melahirkan hak dan kewajiban bagi para pihak, sedangkan law making treaty adalah perjanjian yang kaidahnya dapat berlaku umum tidak hanya mengikat bagi para pihak yang membuat. ${ }^{6}$

Dalam Pasal 2 Konvensi Wina 1969 dijelaskan mengenai pengertian dari negotiating state, contracting state dan third state. Negotiating state means a State which took part in drawing up and adoption of the text of the treaty ${ }^{7}$. Artinya adalah negara yang ikut serta dalam pembuatan dan penerimaan naskah perjanjian. Contracting state means a State has consented to be bound by a treaty wether or not the treaty has enterd into force. ${ }^{8}$ Artinya adalah adalah negara yang terikat pada perjanjian sedangkan third state means a State not a party to the treaty ${ }^{9}$, artinya negara yang tidak menjadi pihak dalam perjanjian.

Mengenai berlakunya perjanjian internasional dikenal adanya asas pacta sunt servanda yang artinya perjanjian mengikat bagi para pihak dan pacta tertiis nec nocent nec prosunt, artinya perjanjian tidak dapat memberikan hak dan kewajiban kepada pihak ke tiga.

Namun terhadap ketentuan tersebut ada beberapa pengecualian, antara lain:

a. Perjanjian yang dapat mempunyai akibat kepada negara ketiga atas persetujuan mereka.

Hal ini diatur dalam Pasal 35 Konvensi Wina 1969 tentang Hukum Perjanjian menyatakan Suatu kewajiban dapat timbul bagi negara ketiga yang berasal dari ketentuan suatu perjanjian yang dibuat dengan sengaja oleh negara-negara pihak dan negara ketiga tadi menerima kewajiban tersebut dalam bentuk tertulis.

\footnotetext{
6 Mochtar Kusumaatmadja dan Etty R. Agoes, 2003, Pengantar Hukum Internasional, Bandung: Alumni, hlm. 122

Pasal 2 (e) Konvensi Wina 1969

Pasal 2(f) Konvensi Wina 1969

Pasal 2 (h) Konvensi Wina 1969
} 
b. Perjanjian yang memberikan hak kepada negara-negara ketiga. Contoh dalam hal ini diterapkannnya Klausula Mosf Favoured Nation (MFN) . MFN adalah suatu mekanisme yang sering dipakai dalam hubungan ekonomi internasional.

c. Perjanjian yang dapat mempunyai akibat pada Negara ketiga tanpa persetujuan negaranegara ketiga. ${ }^{10}$

Pengecualian mengenai hal ini terdapat dalam Pasal 2 (6) Piagam PBB yang antara lain menyatakan bahwa organisasi harus memastikan bahwa negara-negara bukan anggota PBB bertindak sesuai dengan asas PBB sejauh mengkin bila dianggap perlu untuk perdamaian dan keamanan internasional.

d. Perjanjian yang mengikat negara ketiga berdasarkan hukum kebiasaan internasional. ${ }^{11}$

\section{Tinjauan Hukum laut Internasional}

Pengaturan tentang kedaulatan dan jurisdiksi negara di laut telah diatur dalam United Nations Convention on the Law of the Sea (UNCLOS atau Konvensi PBB tentang Hukum laut 1982). Konvensi Hukum laut mengakui hak negara-negara untuk mengklaim atas berbagai zona maritim dengan status hukum yang berbeda-beda, yaitu :

a. Berada di bawah kedaulatan penuh negara meliputi laut pedalaman, laut teritorial dan selat yang digunakan untuk pelayaran internasional;

b. Negara mempunyai jurisdiksi khusus dan terbatas pada zona tambahan;

c. Negara mempunyai jurisdiksi eksklusif untuk memanfaatkan sumber daya alamnya, yaitu zona ekonomi eksklusif dan landas kontinen;

d. Berada di bawah pengaturan internasional khusus, yaitu daerah dasar laut samudra dalam (Kawasan/international Sea bed area);

e. Tidak berada di bawah kedaulatan negara manapun, yaitu laut lepas. ${ }^{12}$

10 Boer mauna, 2005, Hukum Internasional Pengertian Peranan dan Fungsi dalam era Dinamika Global, Bandung : Alumni, hlm. 143-144

11 Pasal 38 Konvensi Wina 1969

12 Mochtar kusumaatmadja dan Etty R Agoes, op.cit, hlm. 171
Pada prinsipnya di laut lepas tidak berlaku kedaulatan negara. Laut lepas merupakan res communis yaitu laut yang terbuka dan bebas bagi semua negara. Beberapa kebebasan itu adalah : kebebasan berlayar, kebebasan penerbangan, kebebasan menangkap ikan dan melakukan riset. Daerah dasar laut yang berada di bawah laut lepas disebut Dasar Laut Samudra dalam ( Seabed Area).

Kawasan atau Area merupakan dasar laut dan samudra dalam beserta tanah di bawahnya yang terletak di luar jurisdiksi nasional. Di kawasan ini negara-negara tidak mempunyai kebebasan untuk memanfaatkan kekayaan alam yang terkandung di dalamnya karena Kawasan merupakan warisan bersama umat manusia (common heritage of mankind) yang pengelolaannya diserahkan kepada Otorita (the International Sea bed Authority)

Konferensi PBB III tentang hukum laut diadakan di Montego bay Jamaica, mulai Desember 1973 sampai September 1982. Konferensi ini merupakan konfrensi yang terpanjang, terbesar dan terpenting dalam sejarah konferensi internasional. Terpanjang karena konferensi berlangsung selama 9 tahun, terbesar karena dihadiri lebih dari 160 negara dengan sekitar 5000 delegasi dan terpenting karena berhasil mencapai kesepakatan berkat adanya kemauan bersama walaupun banyak masalah yang harus diatasi. ${ }^{13}$

Walaupun demikian UNCLOS tidak diterima secara universal karena negara-negara maju seperi Amerika Serikat tidak mau terikat pada Konvensi. Hal ini pada akan melahirkan suatu permasalahan tentang status hukum dari rezim Seabed ini.

Tidak disangkal bahwa sasaran utama yang hendak dicapai melalui rezim ini tidak mungkin terwujud jika terdapat pihak ketiga pada konvensi ini yang secara tegas menolak berlakunya Bab XI. Namun sayangnya dalam mendekati permasalahan ini, para ahli lebih menekankan pada soal ketidakefektifan rezim ini daripada keabsahannya. Dilihat dari segi hukum perjanjian internasional, tidak diterimanya

13 Boer Mauna, op. cit., hlm. 273 
secara umum rezim ini tidak hanya mengakibatkan rezim ini tidak efektif tetapi juga menimbulkan konflik norma dan bahkan mengakibatkan status hukumnya semakin tidak menentu. ${ }^{14}$

Salah satu ciri yang penting adanya rezim ini adalah terjadinya suatu konversi rezim atas wilayah yang dulunya merupakan rezim laut bebas berubah menjadi rezim Seabed/CHM. Perubahan rezim ini tentunya menuntut suatu pemberlakuan secara umum untuk semua negara dalam arti tidak mungkin rezim ini diterapkan terhadap sebagian negara, sementara negara-negara yang lain menerapkan rezim yang lama. Telah dibayangkan oleh negara peserta konferensi bahwa tidak mungkin terdapat dua rezim yang berbeda terhadap satu wilayah yang sama. Itulah sebabnya redaksional Konvensi ini dibuat sedemikian rupa sehingga mengindikasikan bahwa rezim ini berlaku secara universal terhadap semua negara. Istilahistilah seperti all states, every state dan no state disamping state parties banyak digunakan dalam Bab ini membuktikan maksud para pihak konvensi untuk memberikan hak-hak kepada semua negara tersebut. Namun yang menjadi persoalan bahwa dalam hal rezim Seabed hubungan dengan pihak ketiga tidak hanya menyangkut pemberian hak-hak tetapi juga pembebanan kewajiban-kewajiban.

Berdasarkan prinsip ini, maka dapat dimengerti adanya argumentasi yang diterima oleh kebanyakan ahli yang menyatakan bahwa KHL 1982 bersifat suatu kontrak yang tidak mengikat pihak ketiga tanpa persetujuannya. Mungkin dapat mengikat jika ketentuan-ketentuan konvensi telah diterima sebagai bagian dari hukum kebiasaan internasional. ${ }^{15}$ Namun untuk menentukan apakah suatu ketentuan konvensi sudah diterima sebagai hukum kebiasaan adalah merupakan permasalahan klasik hukum internasional dan selalu menghasilkan dua pendapat yang berbeda. Syarat adanya hu-

14 Grolin, Jesper, op. cit., hlm.20

15 Lee Luke T, 1983, "The Law of The Sea Convention and third States", American Journal of International Law, Vol $.77 \mathrm{hlm} .565$ kum kebiasaan internasional ada dua, pertama harus terdapat suatu kebiasaan yang bersifat umum dan kedua kebiasaan itu harus diterima sebagai hokum. ${ }^{16} \mathrm{Hal}$ ini berlaku dalam hal Bab XI KHL 1982. Di satu pihak, Bab tentang Seabed ini dianggap belum memenuhi syarat untuk diterima sebagai hukum kebiasaan.

Dengan diterimanya KHL 1982 khususnya tentang Seabed, maka bagi setiap negara, Konvensi berlaku sebagai hukum kebiasaan. Memang kelihatannya melalui transformasi menjadi hukum kebiasaan ini masalah nonuniversal acceptance dari konvensi dapat diselesaikan. Namun masih ada kendala lain yang dapat membuat hukum kebiasaan tidak universal, yaitu adanya prinsip persistent onjector yang memungkinkan suatu negara tidak terikat ketentuan hukum kebiasaan jika ia secara terusmenerus dan konsisten menyatakan penolakan atas berlakunya ketentuan itu. ${ }^{17}$

Dengan demikian meskipun disepakati diterimanya KHL 1982 sebagai hukum kebiasaan, tidak dengan sendirinya dapat diselesaikan masalah non universal acceptance. Hal ini sekaligus membuktikan bahwa pendekatan-pendekatan tradisional terhadap masalah rezim Seabed tidak lagi relevan. Untuk itu rezim ini perlu dikaji dari segi sifat esensinya.

Sekalipun hukum perjanjian internasional telah meletakkan prinsip bahwa suatu perjanjian tidak memberikan hak atau membedakan kewajiban kepada pihak ketiga tanpa persetujuannya, terdapat pula suatu argumen yang dikemukakan Waldock, Rapporteur khusus dalam proses pembentukan Konvensi Wina 1969 tentang Hukum Perjanjian Internasional, menyebutkan ada dua situasi yang mengakibatkan terikatnya suatu perjanjian terhadap pihak ketiga. Pertama jika perjanjian tersebut membentuk suatu objective regime, yang melahirkan hak dan kewajiban yang berlaku universal (erga omnes). Kedua, jika perjanjian

16 Mochtar Kusumaatmadja dan Etty R. Agoes, op.cit., hlm. 144

17 Pendapat ini didasarkan pada teori Bin Cheng tentang instant customary law, dalam United Nations Resolutions on Outer Space: Instant International Customary Law, Indian Journal of International Law, 1965. 
Penerapan Asas Pacta Tertiis Nec Nocent Nec Prosunt Berkaitan 33

dengan Status Hukum Daerah Dasar Laut Samudera Dalam (Sea Bed)

tersebut telah menjadi hukum kebiasaan internasional. ${ }^{18}$

Brierly juga mengindikasikan bahwa hukum internasional telah mengakui adanya suatu perjanjian yang memiliki sifat obyektif dan mirip dengan produk legislatif, misalnya jika perjanjian tersebut menciptakan suatu situasi internasional atau suatu institusi yang mengikat semua negara baik pihak maupun bukan pihak pada perjanjian tersebut. ${ }^{19}$

McNair juga mengikuti adanya jenis perjanjian yang memiliki karakter constitutive dan semi legislative atau perjanjian yang berkarakter publik yang dibuat melalui keputusan negara-negara besar yang dianggap sebagai wakil kepentingan umum. Starke juga sependapat bahwa perjanjian-perjanjian tertentu yang oleh para pihak diharapkan berlaku secara universal dapat saja mengikat pihak ketiga. Sebagai contoh, ia menunjuk pada Single Convention on Narcotic Drug 1961, yang memungkinkan suatu organisasi internasional untuk menentukan kuota narkotik bagi suatu negara baik pihak maupun yang bukan pihak pada Konvensi tersebut. ${ }^{20}$

Komisi Hukum Internasional dalam draft Konvensi Wina 1969, khususnya yang menyangkut masalah hubungan perjanjian dengan pihak ketiga berusaha mencakup permasalahan rezim obyektif ini. Beberapa anggota menyatakan bahwa perjanjian yang memuat rezim obyektif diakui dan terdapat dalam hukum internasional dan perlu mendapat pengaturan melalui konvensi. Mereka menyatakan bahwa hal-hal yang masuk dalam perjanjian ini adalah berkaitan dengan netralisasi dan demiliterisasi dari suatu teritorial atau wilayah kebebasan navigasi sungai-sungai internasional. Contoh klasik dari rezim ini adalah The Antartic Treaty. Namun di lain pihak, beberapa anggota sekalipun tidak menolak eksistensi jenis perjanjian tersebut beranggapan bahwa dasar mengikat untuk pihak ketiga bukan dari perjanjian tersebut, me-

18 Gillian Triggs, 1986, International Law and Australian Souvereignty in Antartica, Sidney, hlm. 140-144.

19 Ibid.

20 Starke, 1995, Pengantar Hukum Internasional terjemahan Bambang Iriana D., Jakarta: Sinar Grafika, hlm. 466. lainkan melalui hukum kebiasaan yang ditransformasikan dari perjanjian tersebut. Mengingat tidak adanya kesepakatan dalam hal dasar pengikatan perjanjian ini, maka komisi memutuskan untuk menangguhkannya dan tidak membuat pengaturan dalam Konvensi Wina 1969.

Tidak diaturnya perjanjian pembentukan rezim objektif ini dalam Konvensi tidaklah berarti menyangkal sama sekali eksistensi perjanjian jenis ini. Hal ini harus diartikan bahwa saat ini belum mendesak untuk dibuat suatu pengaturan khusus tentang perjanjian-perjanjian tersebut.

Jika ditelusuri secara teliti, kelompok yang paling keras menolak adanya rezim objektif pada waktu itu adalah negara-negara sosialis. Mereka berpegang teguh pada prinsip pacta tertiis yang meletakkan kedaulatan negara di atas segala-galanya sehingga mensyaratkan adanya persetujuan pada setiap perjanjian yang akan membebankan suatu kewajiban kepada pihak ketiga.

Desakan untuk diakuinya eksistensi objective regime valid erga omnes juga didukung oleh jurisprudensi seperti misalnya dalam International Status of South West Africa yang berpendapat :

From time to time it happens that a group of graet powers or a large number of States both great and small, assume a power to create by a multipartite treaty some new international regime or status, which soon extends beyond the limit of actual contracting parties and giving it an objective existence. This power is used where some public interest is involved.

Seperti telah diketahui, masalah kontroversi yang mengitari rezim obyektif ini adalah apa dasar mengikat dari erga omnes. Pendekatan tradisional seperti yang dianut oleh sebagian besar anggota komisi pada saat merancang Konvensi Wina 1969, lebih menitikberatkan sumber mengikatnya pada hukum kebiasaan. Namun pendekatan ini tidak dapat menjawab bagaimana Antartic Treaty yang disebut sebagai contoh klasik dari rezim objektif dapat mengikat secara erga omnes melalui kebiasaan. Padahal, traktat ini tidak dapat di- 
anggap sebagai hukum kebiasaan yang mengingat para pihak pada perjanjian ini hanya sebagian kecil negara. Itulah sebabnya, McNair lebih menekankan bahwa efek erga omnes tersebut tidak bersumber dari hukum kebiasaan melainkan unsur yang inherent unik pada perjanjian tersebut.

Selain itu ada pula pandangan yang cukup progresif yang berpendapat bahwa wilayahwilayah tertentu yang tidak di bawah yuridiksi negara seperti laut bebas, Seabed dan ruang angkasa harus ditempatkan di bawah kekuasaan masyarakat internasional seperti PBB. Berdasarkan hukum internasional, organisasi tersebut dapat mengeluarkan peraturan-peraturan yang mengikat semua negara.

Setelah menelusuri dan merangkum pandangan para ahli di atas dan mengkaji karakter hukum dari rezim Seabed seperti yang termuat pada Bab XI KHL 1982, maka terdapat suatu indikasi kuat bahwa rezim ini merupakan an objective regime valid erga omnes. Paling tidak ada empat indikator yang merujuk pada kesimpulan tersebut. ${ }^{21}$

Pertama, melalui rezim ini terjadi suatu perubahan rezim hukum yang berlaku pada Seabed, dari rezim hukum laut bebas menjadi rezim Seabed versi Konvensi, dari konsep res communis menjadi konsep CHM. Kedua, konsep ini sangat berbeda. Res Communis mengandung implikasi sebagai kebebasan buat semua negara. Semua negara bebas untuk memanfaatkan dan bahkan menyalahgunakan wilayah Seabed. Sedangkan konsep CHM menekankan bahwa pengelolaan Seabed merupakan masalah masyarakat internasional secara keseluruhan yang harus diputuskan oleh masyarakat itu dan bukan oleh negara-negara secara individu. Perubahan rezim hukum di suatu wilayah haruslah bersifat erga omnes, jika tidak maka perubahan rezim hukum tersebut tidak memiliki arti dan kehilangan dasar hukum. Tidak mungkin sebagian negara terikat pada rezim Seabed se-

21 Damos Dumoli Agusman, 1986, “ Regim Seabed: Apakah Berlaku Erga Omnes”, Jurnal Hukum Internasional, UNPAD, Bandung , hlm. 71 mentara negara yang lain tunduk pada rezim laut bebas.

Kedua, rezim Seabed dimaksudkan untuk menguasai suatu wilayah milik umat manusia. Pasal 153 (1) menyatakan bahwa rezim ini akan menguasai wilayah secara ekslusif tempat semua kegiatan di wilayah ini dilakukan dan diawasi oleh Authority atas nama dan untuk kepentingan seluruh umat manusia (bukan negara). Dengan demikian rezim ini mengandung unsur publik (kepentingan masyarakat internasional).

Ketiga, rezim ini membentuk suatu organisasi internasional yang memiliki personalitas obyektif yang oleh hakim pada Reparation of Injuries Case 1949, berlaku secara universal atau erga omnes terhadap anggota atau bukan anggota. Demikian halnya dengan International Authority, badan ini haruslah dianggap memiliki personalitas objektif yang berlaku untuk semua negara, baik pihak atau bukan pada KHL 1982.

Keempat, rezim ini diciptakan oleh mayoritas negara-negara. Telah banyak yang menyatakan bahwa proses negosiasi dalam Konferensi Hukum laut yang lalu merupakan refleksi dari adanya pergerakan demokratisasi di dalam hubungan internasional. Dalam konperensi inilah, ditampilkan bahwa pengambilan keputusan dalam masalah-masalah yang menyangkut kepentingan masyarakat internasional tidak lagi berdasarkan kekuasaan melainkan demokrasi.

Keempat karakter ini jelas mendorong setiap pihak untuk tidak menyangkal dan berkesimpulan bahwa rezim Seabed adalah objecttive regime dan berlaku erga omnes. Prinsip erga omnes, misalnya terlihat dalam Pasal 137 :

(1) No State shall claim or exercise sovereignty or souveregn rights over any part of the Area of its resources, nor shall any State or natural or judicial person appropriate any part thereof. No such claim or axercise of soeverignty or souveregn rights nor such appropriation shall be recognized.

(2) No State or natural or judicial person shall claim, acquire or exercise rights with respect to the minerals recovered from the Area except in accordance with this 
Part. Otherwise, no such claim, acquisition or exercise of such rights shall be recognized.

Penggunaan istilah no state dan any state pada pasal ini secara jelas menunjuk pada semua negara tanpa terkecuali. Dengan kata lain, jika pasal ini hanya melarang para pihak konvensi dan pihak lain, maksud dan tujuan pasal ini tidak akan tercapai.

Salah satu ciri esensial dari adanya rezim ini adalah terjadinya suatu konversi rezim atas wilayah Area yang dulu merupakan rezim laut bebas yang berubah menjadi rezim Seabed/ CHM. Perubahan rezim ini tentunya menuntut suatu pemberlakuan secara umum untuk semua negara dalam arti tidak mungkin rezim ini dapat diterapkan terhadap sebagian negara, sementara negara-negara lain menerapkan rezim lama.

\section{Penutup}

\section{Simpulan}

Asas pacta tertiis nec nocent nec prosunt yang artinya perjanjian tidak dapat memberikan hak dan kewajiban kepada negara ketiga dapat dikecualikan. Berkaitan dengan status hukum Seabed yang menjadi warisan bersama umat manusia (common heritage of The mankind) dan pengelolaannya diatur oleh suatu badan internasional (Authority) maka rezim ini berlaku secara universal (erga omnes) baik itu bagi negara peserta maupun bukan negara peserta Konvensi Hukum laut 1982. 